\title{
Sensory profile of conilon coffee brews from the state of Espírito Santo, Brazil
}

\author{
André Luiz Buzzo Mori(1), Aline de Oliveira Garcia(2), Maria Amélia Gava Ferrão(3), \\ Aymbiré Francisco Almeida da Fonseca ${ }^{(3)}$, Romário Gava Ferrão( ${ }^{(4)}$ and Marta de Toledo Benassi ${ }^{(1)}$
}

\begin{abstract}
(1)Universidade Estadual de Londrina, Rodovia Celso Garcia Cid, Km 380, s/no-, Campus Universitário, CEP 86057-970 Londrina, PR, Brazil. E-mail: buzzo.mori@gmail.com, martatb@uel.br (2Instituto de Tecnologia de Alimentos, Avenida Cônego Antônio Roccato, no 140, Vila Nova, CEP 13070-178 Campinas, SP, Brazil. E-mail: alinegarcia@ital.sp.gov.br ${ }^{(3)}$ Embrapa Café, Parque Estação Biológica, Avenida W3 Norte (Final), CEP 70770-901 Brasília, DF Brazil. E-mail: maria.ferrao@embrapa.br, aymbire.fonseca@embrapa.br ${ }^{(4)}$ Instituto Capixaba de Pesquisa, Assistência Técnica e Extensão Rural, Rua Afonso Sarlo, no 160, Bento Ferreira, CEP 29052-010 Vitória, ES, Brazil. E-mail: ferrao.romario@gmail.com
\end{abstract}

\begin{abstract}
The objective of this work was to present a sensory description of conilon coffee (Coffea canephora) brews produced from genotypes developed for the state of Espírito Santo, Brazil. The genotypes 'Diamante ES8112', 'ES8122', and 'Centenária ES8132' were evaluated. Nine samples from three clones (genotypes) of each cultivar, from two different regions of the state, were analyzed. A panel of tasters for coffee sensory evaluation was trained to obtain a descriptive profile and to select terms. Beverages were described as showing a higher intensity of powder fragrance, characteristic aroma of coffee brew, body, characteristic flavor and aftertaste, and a lower intensity of bitterness, acidity, astringency, and defects. The terms bitterness, strong, body, astringency, and coffee aftertaste were the most relevant in the characterization of the beverages of the studied C. canephora cultivars. Acidity is the attribute with the greatest impact on the overall quality of $C$. canephora brew. The coffee brews of the clones of 'Diamante ES8112', 'ES8122', and 'Centenária ES8132' are classified as of traditional quality, but near the superior category.
\end{abstract}

Index terms: Coffea canephora, Centenária ES8132, Diamante ES8112, ES8122, sensory analysis.

\section{Perfil sensorial de bebidas de café conilon do Estado do Espírito Santo}

Resumo - O objetivo deste trabalho foi apresentar uma descrição sensorial de bebidas de café conilon (Coffea canefora) produzidas a partir de genótipos desenvolvidos para o Estado do Espírito Santo. Foram avaliados os genótipos 'Diamante ES8112', 'ES8122' e 'Centenária ES8132'. Nove amostras oriundas de três clones (genótipos) de cada cultivar, procedentes de duas regiões distintas do estado, foram analisadas. Uma equipe de testadores para a avaliação sensorial de café foi treinada para a obtenção do perfil descritivo e a seleção de termos. As bebidas de café foram descritas como apresentando uma maior intensidade dos atributos fragrância do pó de café, aroma característico da bebida, corpo, sabor característico e sabor residual, e uma menor intensidade de amargor, acidez, adstringência e defeitos. Os termos amargor, forte, encorpado, adstringência e sabor residual característico de café foram os mais relevantes na caracterização das bebidas das cultivares de C. canephora estudadas. A acidez é o atributo com maior impacto sobre a qualidade global da bebida de C. canephora. As bebidas dos clones das cultivares 'Diamante', 'ES8122' e 'Centenária ES8132' classificam-se como na faixa de qualidade tradicional, porém próxima à categoria superior.

Termos para indexação: Coffea canephora, Centenária ES8132, Diamante ES8112, ES8122, análise sensorial.

\section{Introduction}

Brazil is the largest coffee country in the world, with an estimate of 44.77 million bags $(60 \mathrm{~kg})$ for the 2017 crop season. Currently, it is the second largest conilon coffee (Coffea canephora) producer, with the production concentrated in the states of Espírito Santo (58\%) and Rondônia (18\%) (Acompanhamento..., 2017).
Overall, C. canephora production grew more than $400 \%$ in the last 56 years, from 12.6 million bags in 1960 , to 66.6 million bags in the $2015 / 2016$ season (USDA, 2017). Coffea canephora has assisted Brazil to maintain its position as the largest coffee grower in the world. In the 2017 season, it represented approximately $24 \%$ of the total Brazilian production (Acompanhamento..., 2017). Another relevant aspect of this species is its adaptation to regions with low

Pesq. agropec. bras., Brasília, v.53, n.9, p.1061-1069, Sept. 2018 DOI: $10.1590 / \mathrm{S} 0100-204 X 2018000900010$ 
altitude and high temperatures, and its resistance to prolonged water deficits (Ferrão et al., 2017), which allows of the expansion of the planted area, as it shows fewer restrictions for growing regions than C. arabica.

The $C$. canephora breeding program of Instituto Capixaba de Pesquisa, Assistência Técnica e Extensão Rural (Incaper) has developed different genotypes of high yield, adaptation, and production stability associated to other important agronomic characteristics, such as cup-quality and maturation of fruit in different seasons. The use of cultivars with different fruit-ripening seasons (early, medium, and late maturation) is advantageous for the coffee grower, as they allow of harvesting in a staggered way and during a longer period, with a better management of the workforce and of the use of coffee yards and dryers (Ferrão et al., 2009, 2017).

Coffee quality varies along the production chain, which goes from the coffee-grower to the endconsumer. For growers, it varies by join productivity, price, and crop facility, while for consumers, coffee quality is associated with price, flavor, and aroma, health effects, geographical origin, and environmental and sociological aspects (Leroy et al., 2006).

The Associação Brasileira da Indústria de Café (ABIC) recommends a sensory evaluation of the overall quality of the beverages, in order to monitor the quality of roasted coffee commercialized in Brazil (ABIC, 2017). This requirement is already present in specific legislation of some states in the country that are traditional producers of C. arabica. The state of São Paulo stands out for having a regulation establishing the minimum quality standards for classification, such as the Resolutions SAA no. 30 and no. 31 of June 22, 2007, and SAA no. 19 of April 5, 2010 (São Paulo, 2007b, 2007c, 2010). Other Brazilian states adopt similar criteria for purchasing roasted coffee products for consumption in the public administration sphere, as those described by the decree 2916 of 06/25/2008 from Paraná state (Paraná, 2008), decree 44.661 of 11/26/2007 from Minas Gerais state (Minas Gerais, 2007), and decree 1674-R of 05/25/2006 from Espírito Santo state (Espírito Santo, 2006). The cupquality evaluation of the coffee brewd was included as mandatory in the national legislation, according to the Normative Instruction 16/2010 (Brasil, 2010), revoked later by the Normative Instruction 7/2013 (Brasil, 2013), justified by the difficulty in maintaining trained sensory panels and certified laboratories to carry out the evaluation.

It is important to highlight that any roasted coffee sold in Brazil - regardless of the species - certified by the Coffee Quality Program (CQP), or subjected to inspection by state and federal agencies, is subjected to a coffee brew sensory quality evaluation. The evaluation is based on the ABIC quality regulation (ABIC, 2017), or on specific standards for each Brazilian state, whenever applicable. Based on the CQP, roasted coffee brews with General Recommendable Quality, either coffee beans or grounded coffee, are those constituted of $C$. arabica, or blended with $C$. canephora, that meet the overall quality requirements by ABIC (2017). However, the sensory characteristics evaluated by current regulations apply to characteristics of $C$. arabica brews, undervaluing the quality evaluation in the case of the inclusion of C. canephora in the blends. Except for Moura et al. (2007), who studied the effect of adding C. canephora to blends, the literature shows no studies related to the quality of beverages of this coffee species.

The objective of this work was to present a sensory description of $C$. canephora brews produced from genotypes of clonal cultivars developed for the state of Espírito Santo, Brazil.

\section{Materials and Methods}

Three genotypes from C.canephora clonal cultivars, developed by the genetic breeding program of Incaper, were analyzed. These clonal cultivars are formed by a group of nine compatible clones (genotypes) used to obtain the crops. In the present study, three clones of each cultivar were evaluated. The cultivars showed distinct fruit-ripening seasons: early maturation for 'Diamante ES8112' (genotypes 103P, 105P, and 106P); medium maturation for 'ES8122', also known as Jequitibá (genotypes 201I, 203I, and 209I); and late maturation for 'Centenária ES8132' (genotypes 301T, 303T, and 306T), according to Incaper ('Centenária ES8132'..., 2015; 'Diamante ES8112'..., 2015; 'ES8122' Jequitibá..., 2015).

Samples (500 $\mathrm{g}$ of each coffee genotype) were collected during 2014, from 36-month-old representative crops, in different regions of the state of Espírito Santo, as follows: an experimental farm of Marilândia, located in the municipality of Marilândia, in the northwestern region of the state $\left(19^{\circ} 24^{\prime} \mathrm{S}\right.$, 
$40^{\circ} 31^{\prime} \mathrm{W}$ ); and experimental farm of Bananal Norte, in the municipality of Cachoeiro do Itapemirim, in the southern region of the state $\left(20^{\circ} 75^{\prime} \mathrm{S}, 41^{\circ} 29^{\prime} \mathrm{W}\right)$. Manual harvesting of early-maturing genotypes started in May and was followed by that of mediummaturing (June) and late-maturing (July) ones; only cherry-stage fruit were collected. Coffee was dried in the coffee yard, in the sun, and then it was processed. Nondefective beans of sieve size $16(6.5 \mathrm{~mm})$ were selected. Green coffees were kept in plastic bags at room temperature, until roasting in February 2016.

Each sample (genotype) was represented by a mixture of the green beans originated from each experimental farm. Samples were roasted in a gas pilot roaster (Rod Bel, São Paulo, SP, Brazil) for 15-17 min, at temperatures between 210 and $230^{\circ} \mathrm{C}$. Roasting was standardized to obtain weight loss of $16.5 \pm 0.2 \mathrm{~g} 100 \mathrm{~g}^{-1}$, described by Mendes et al. (2001) as the optimum for C. canephora. Coffees showed a roast degree of $65.8 \pm 6.7$, evaluated by the E10-CP process analyzer (Agtron Inc., Reno, NV, USA), corresponding to a medium to light roasting, according to the Agtron System.

Samples were ground at fine granulometry, according to the recommendation of ABIC (2017), using the Top laboratory mill (La Spaziale Brasil \& America Latina, São Paulo, SP, Brazil).

The coffee brew was prepared, according to the ABIC recommendations (ABIC, 2017), through percolation with paper filter (Melitta, São Paulo, SP, Brazil), using $50 \mathrm{~g}$ of roasted and ground coffee to $500 \mathrm{~mL}$ of mineral water (Ouro Fino, Curitiba, PR, Brazil), at the $1: 10$ proportion of coffee:water, at $92^{\circ} \mathrm{C}$. The samples were stored in thermal bottles and kept until analyses, up to $30 \mathrm{~min}$.

Beverages were characterized for caffeine and total chlorogenic acid contents according to Corso et al. (2016), and total titratable acidity according to Scholz et al. (2013). Analyses were carried out in duplicate, and results were expressed as a range for each cultivar (considering the three genotypes, and the two growing sites). Caffeine and chlorogenic acids $\left(\mu \mathrm{g} \mathrm{mL} \mathrm{m}^{-1}\right.$ of coffee brew), and the total titratable acidity ( $\mathrm{mL}$ of sodium hydroxide for $20 \mathrm{~mL}$ of the coffee brew) were reported.

Sensory analyses were carried out at the laboratory of physical and sensorial analysis of Instituto de Tecnologia de Alimentos de Campinas (Ital), and registered in the laboratory network for sensory evaluation of coffee brew quality (ABIC, 2017). The sensory panel, previously trained, was composed by ten assessors, between 28 and 56 years of age, including three men and seven women. This panel is retrained and validated annually, and participants' experience with coffee sensorial evaluation was between 5 to 10 years.

The analyses were performed under red light in individual booths, equipped with the Compusense Five system, version 5.6 (Compusense, Guelph, ON, Canada), for data collection. Data were analyzed by the XLStat 2016.01.26779 software (Addinsoft, Paris, France).

Assessors received $50 \mathrm{~mL}$ of the beverages (at a temperature between 66 and $69^{\circ} \mathrm{C}$ ) in porcelain cups, black inside and white outside, identified with a randomized three-digit code. Samples were presented in a monadic way. During the session, the assessors first evaluated the descriptive profile of the coffee brew, and then they started the procedure of term selection. The order of presentation of the samples was randomized for each assessor. Three sessions were performed, and during each one, three different samples were evaluated, to obtain a genuine duplicate of each coffee brew.

The research was approved by the human research ethics committee of Universidade Estadual de Londrina (CAAE 21939713.3.0000.5231).

The descriptive profile analysis was carried out according to the Resolution SAA no. 30 of June 22, 2007, and SAA no. 28 of June 1, 2007 (São Paulo, $2007 \mathrm{a}, 2007 \mathrm{c}$ ), in a procedure equivalent to that advocated by ABIC (2017). The assessors filled out an individual score sheet for each sample, at each evaluation. Each parameter - powder fragrance, characteristic aroma of coffee brew, defects, acidity, bitterness, characteristic flavor of coffee brew, residual flavor (aftertaste), body, and astringency -, as well as the overall quality of the beverages, were evaluated individually using an unstructured $10 \mathrm{~cm}$ scale. One sample classified as superior was used as a reference, similarly to the described by Moura et al. (2007) and Mori et al. (2003). Data were evaluated by the analysis of variance, considering the samples as the source of variation, and Tukey's test, at $10 \%$ probability. Results for each parameter were expressed as mean

Pesq. agropec. bras., Brasília, v.53, n.9, p.1061-1069, Sept. 2018 DOI: 10.1590/S0100-204X2018000900010 
values for the sensory panel (duplicate analysis and ten assessors).

For the overall quality parameter, the analysis was based on the Resolutions SAA no. 19, SAA no. 30, and SAA no. 31 , which define the minimum quality standards for roasted coffee; for beans and grounded coffee, classified as traditional, coffee shows an overall quality score from 4.5 to 6.0 ; for the rank superior, overall quality score is from 6.0 to 7.3; or gourmet, overall quality score from 7.3 to 10 (São Paulo, 2007b, 2007c, 2010).

For the procedure for selection of terms, a Focus Group session was previously performed, in order to choose the descriptive terms to be used. The 172 terms presented in the flavor wheel from Specialty Coffee Association of America (SCAA) - 94 of which are associated to coffee characteristics, and 78 are associated with coffee defects (SCAA, 2015) - were used for discussion. The group was requested to highlight the term related to Brazilian roasted coffees, which were noticed during routine sensory evaluations. Therefore, 22 terms were selected for further sample analyses, as follows: sweet, acid, bitter, slightly sweet, slightly acid, slightly bitter, astringent, nutty/hazelnut, chocolate, watery, characteristic residual flavor of coffee, floral/fruity, smoky/tobacco, strong, weak, burnt, caramelized, herb-like/tea, fullbodied, noncharacteristic residual flavor, spice/black pepper/nutmeg, and chemical/resinous/medicinal.

The evaluation was done straight after the descriptive profile. Assessors were asked to select the terms among the 22 previously defined, which would apply to coffee brews. Terms presentation order was randomized for each sample and assessor, according to Ares et al. (2014). Among the 22 presented terms, the selected ones were those showing difference in the frequency of citation among coffee brews at $20 \%$ probability, and those cited by more than $20 \%$ of the assessors. Terms selection results were reported as frequency of citation and were subjected to the Cochran Q-test, followed by the Marascuilo multiple comparison test, at $5 \%$ probability.

\section{Results and Discussion}

In general, the scores of the coffee brews from the genotypes of three $C$. canephora cultivars were classified in the categories traditional and superior
(Table 1). Except for acidity and overall quality, there was no difference among the mean scores of the attributes for the nine coffee brews evaluated, considering the three genotypes of each of the three cultivars.

Coffee brews showed a high intensity of the attributes powder fragrance, characteristic aroma of coffee brew, body, characteristic flavor of coffee brew, and residual flavor with mean scores from 5.6 to 6.1 (Table 1). The body of coffee brews of the three evaluated cultivars (mean score 6.0) was superior to that reported by Aguiar et al. (2001), who obtained values between 4.81 and 5.66 for beverages of three C. arabica cultivars (Ouro Verde, Tupi, and Obatã). The panel showed consensus, that is, coefficients of variation between 8 and $11 \%$, in describing these attributes, even considering that they were evaluating C. canephora beverages. The coffee brews were also described as showing less bitterness (mean score 4.6), acidity (scores from 3.6 to 4.1), and astringency (mean score 3.8). Moura et al. (2007) reported a score of 3.4 for astringency of $100 \%$ C. canephora beverage, similarly to that observed in the present study. The authors also reported that the C. canephora brew showed acidity score of 1.9 , which is inferior to the obtained one for a beverage of $100 \%$ C. arabica (score 3.6). It is important to emphasize that coffee brews in the present study obtained acidity scores close to those reported by Moura et al. (2007) for a C. arabica brew.

Acidity was the only specific attribute for which the difference between cultivars was observed. The beverage from 'Diamante ES8112', genotype 105P, was described as less acid than that from the 'ES8122', genotype 202I (Table 1). For the attributes acidity and astringency, a great variability (CV around $16 \%$ ) was observed among the scores assigned by the panel.

The sensory parameters and ranges required by the recommendations are characteristic of beverages of $C$. arabica species. Therefore, it was expected that some specific sensory attributes of the $C$. canephora coffee brew, such as low acidity and bitterness, and marked astringency (Williams et al., 1989) could cause a disadvantage for the classification of $C$. canephora beverages. However, thesebeverageparameters(Table 1) were very near to the superior category, according to resolution SAA no. 28 of June 1, 2007 (ABIC, 2017).

Although the raw material used in the present study had no defects and coffee was collected and processed 
under adequate conditions, beverages from genotypes of the three cultivars were described as showing defects (score 3.6) (Table 1). It should be highlighted that the parameter "defect" showed the greater variability among the assessors (CV of 21\%), indicating a greater difficulty and lesser consensus in the evaluation by the panel. Probably, according to the sensory evaluation protocol used, specific characteristics of C. canephora beverages may have been considered as "defects". However, the defect scores were inferior to those reported by Schmidt et al. (2012) for C. arabica 'Iapar 59', cultivated in the state of Paraná in different types of soil, and subjected to medium and dark-roasting processes (scores from 5.01 to 5.54).

Beverages from genotypes of the three cultivars had overall quality scores from 5.5 to 6.0 (Table 1), at the superior limit of the traditional category. These scores were higher than those reported by Moura et al. (2007) for a coffee blend with $70 \%$ of C. arabica (score 5.4) and by Schmidt et al. (2012) for C. arabica 'Iapar 59' (with 4.32 to 4.88). The beverage from cultivar 'ES8122' genotype 202I was distinguished by an overall quality score of 6.0 (superior quality coffee), which is higher than that assigned to the beverage from 'Diamante ES8112' genotype 105P (Table 1). This behavior stressed the importance of acidity to the overall quality evaluation of coffee brews.

When evaluated by the specific protocol for C. canephora of the Coffee Quality Institute, conilon coffee brews of 'Diamante ES8112', 'ES8122', and 'Centenária ES8132' stood out for showing a high-cup quality, from 77.50 to 79.01 , and were classified as "Premium" with 70 to 80 points ('Centenária ES8132'..., 2015; 'Diamante ES8112'..., 2015; 'ES8122' Jequitibá..., 2015). The present research confirms this information, and shows that even when evaluated by a general protocol, the genotypes from the evaluated cultivars showed a good potential that was considered close to a superior category coffee brew. There is a great interest in cultivars that show distinct fruit-ripening seasons and greater production viability (staggered harvesting, helping labor management, and the use of coffee yards and dryers). It is also important that these cultivars have similar coffee brew sensory characteristics, to allow of the production of C. canephora with good quality in a longer period during the year; besides, the characteristics of these cultivar allow of the use of the studied genotypes in greater quantities and proportion by the industry.

In the descriptive analysis using the selection of the terms, out of the 22 ones presented, 15 terms were selected based on their high citation and greater difference in the frequency of citation (Table 2). In general, the terms bitterness, strong, full-bodied, astringency, and characteristic residual flavor of coffee were the most relevant in the characterization of the coffee brews from genotypes of the three C. canephora cultivars (Table 2). The perception of bitterness was

Table 1. Descriptive profile of conilon coffee (Coffea canephora) brews from Diamante ES8112, ES8122, and Centenária ES8132 cultivars, according to the Resolutions SAA-30 and SAA-28 (São Paulo, 2007a, 2007c) ${ }^{(1)}$.

\begin{tabular}{|c|c|c|c|c|c|c|c|c|c|c|}
\hline \multirow[t]{3}{*}{ Parameter } & \multicolumn{9}{|c|}{ Cultivar $^{(2)}$} & \multirow{3}{*}{$\begin{array}{l}\text { LSD } \\
10 \%\end{array}$} \\
\hline & \multicolumn{3}{|c|}{ Diamante ES8112 (early maturing) } & \multicolumn{3}{|c|}{ ES8122 (medium maturing) } & \multicolumn{3}{|c|}{ Centenária ES8132 (late maturing) } & \\
\hline & $103 \mathrm{E}$ & $105 \mathrm{E}$ & $106 \mathrm{E}$ & $202 \mathrm{M}$ & $203 \mathrm{M}$ & $209 \mathrm{M}$ & $301 \mathrm{~L}$ & $303 \mathrm{~L}$ & $306 \mathrm{~L}$ & \\
\hline Powder fragrance & $6.3(0.7)$ & $5.9(0.8)$ & $6.0(0.7)$ & $6.3(0.4)$ & $6.1(0.7)$ & $6.1(0.6)$ & $6.2(0.8)$ & $6.2(0.6)$ & $6.3(0.6)$ & 0.55 \\
\hline $\mathrm{CACB}$ & $6.2(0.8)$ & $5.8(0.8)$ & $6.0(0.6)$ & $6.2(0.4)$ & $6.0(0.6)$ & $5.9(0.7)$ & $6.1(0.8)$ & $6.0(0.6)$ & $6.1(0.6)$ & 0.57 \\
\hline Defects & $3.6(0.7)$ & $3.8(1.0)$ & $3.6(0.8)$ & $3.2(0.4)$ & $3.4(0.6)$ & $3.6(0.7)$ & $3.7(0.9)$ & $3.5(0.9)$ & $3.5(0.7)$ & 0.69 \\
\hline Acidity & $3.8 \mathrm{ab}(0.7)$ & $3.6 b(0.7)$ & $3.7 \mathrm{ab}(0.5)$ & $4.1 \mathrm{a}(0.4)$ & $3.9 \mathrm{ab}(0.6)$ & $3.7 \mathrm{ab}(0.7)$ & $3.8 \mathrm{ab}(0.6)$ & $3.8 \mathrm{ab}(0.7)$ & $3.9 \mathrm{ab}(0.5)$ & 0.44 \\
\hline Bitterness & $4.8(0.5)$ & $4.8(0.7)$ & $4.6(0.5)$ & $4.4(0.4)$ & $4.6(0.6)$ & $4.7(0.6)$ & $4.8(0.8)$ & $4.6(0.5)$ & $4.6(0.5)$ & 0.53 \\
\hline $\mathrm{CFCB}$ & $5.8(0.6)$ & $5.6(0.8)$ & $5.8(0.7)$ & $6.1(0.5)$ & $5.9(0.6)$ & $5.8(0.7)$ & $5.8(0.6)$ & $5.9(0.5)$ & $6.0(0.6)$ & 0.57 \\
\hline Residual flavor & $5.8(0.6)$ & $5.6(0.7)$ & $5.8(0.7)$ & $6.1(0.4)$ & $5.8(0.6)$ & $5.7(0.6)$ & $5.8(0.7)$ & $5.9(0.5)$ & $5.9(0.6)$ & 0.55 \\
\hline Astringency & $3.7(0.4)$ & $3.9(0.6)$ & $3.8(0.6)$ & $3.5(0.6)$ & $3.7(0.6)$ & $3.9(0.8)$ & $3.8(0.6)$ & $3.8(0.4)$ & $3.7(0.5)$ & 0.46 \\
\hline Body & $6.0(0.5)$ & $6.1(0.6)$ & $6.0(0.7)$ & $6.1(0.4)$ & $6.0(0.6)$ & $6.1(0.5)$ & $6.1(0.4)$ & $6.2(0.3)$ & $6.1(0.5)$ & 0.38 \\
\hline Overall quality & $5.7 \mathrm{ab}(0.6)$ & $5.5 \mathrm{~b}(0.8)$ & $5.7 \mathrm{ab}(0.6)$ & $6.0 \mathrm{a}(0.4)$ & $5.8 \mathrm{ab}(0.6)$ & $5.7 \mathrm{ab}(0.5)$ & $5.8 \mathrm{ab}(0.7)$ & $5.9 \mathrm{ab}(0.5)$ & $5.9 \mathrm{ab}(0.5)$ & 0.54 \\
\hline
\end{tabular}

${ }^{(1)}$ Mean \pm (standard deviation) of sensory panel (ten assessors), with two evaluations per sample. ${ }^{(2)}$ Numbers refer to the genotypes of cultivars. Means unidentified with letters do not differ significantly by the Tukey's test, at $10 \%$ probability, from the others in the same row. Means followed by different lowercase letters, in the same row, differ significantly between genotypes, by Tukey's test, at 10\% probability. LSD, least significant difference; CACB, characteristic aroma of coffee brew; CFCB, characteristic flavor of coffee brew. 
highlighted, and it was mentioned by assessors for all beverages, and frequency of citation varied from 50 to $77 \%$. The term slightly bitter was mentioned, but in a much lower proportion. Astringency (22 a 44\%), coffee characteristic flavor, and the terms strong and full-bodied were also considerably cited for all coffee brews. Gloess et al. (2013) compared sensory and composition characteristics of coffee brews prepared by different methods, and concluded that caffeine content is positively associated with bitterness, and the content of chlorogenic acids, with astringency.

Beverages from the genotypes of 'Diamante ES8112', 'ES8122', and 'Centenária ES8132' showed caffeine content from 1,176 to $1,660 \mu \mathrm{g} \mathrm{mL}^{-1}$ (Table 3). Caffeine content of 314 to $1,153 \mu \mathrm{g} \mathrm{mL} \mathrm{mL}^{-1}$ was reported for $C$. canephora beverages (Rodrigues et al., 2007; Perrone et al., 2012), but the coffee brews were prepared with a lower proportion of coffee/water than that reported by the present study. Perrone et al. (2012) found total chlorogenic acids from 633.8 to $1,417.5 \mu \mathrm{g} \mathrm{mL}{ }^{-1}$, for C. canephora beverages (produced with coffee roasted with weight loss near to that of the present study); these values are similar to those of 493 to $1,130 \mu \mathrm{g} \mathrm{mL} \mathrm{m}^{-1}$, observed in the present study, for coffee brews from the three cultivars (Table 3 ).

The term acid was mentioned, but there was a high perception that the beverages showed low acidity (Table 2). The term slightly acid showed a difference in the frequency of citation among the beverages, varying from 'Centenária ES8132' (genotype 303T), less acid, with $44 \%$ of the citations to 'ES8122' (genotype 203I), with $5 \%$ of citations.

Table 2. Frequency of citation of terms for the three genotypes of the three cultivars (Diamante ES8112, ES8122, and Centenária ES8132) of conilon coffee (Coffea canephora) ${ }^{(1)}$.

\begin{tabular}{|c|c|c|c|c|c|c|c|c|c|c|}
\hline \multirow[t]{3}{*}{ Parameter } & \multirow{3}{*}{ p-value } & \multicolumn{9}{|c|}{ Frequency of citation $(\%)^{(2)}$} \\
\hline & & \multicolumn{3}{|c|}{$\begin{array}{c}\text { Diamante ES8112 } \\
\text { (early maturing) }\end{array}$} & \multicolumn{3}{|c|}{$\begin{array}{c}\text { ES8122 } \\
\text { (medium maturing) }\end{array}$} & \multicolumn{3}{|c|}{$\begin{array}{l}\text { Centenária ES8132 } \\
\text { (late maturing) }\end{array}$} \\
\hline & & $103 \mathrm{E}$ & $105 \mathrm{E}$ & $106 \mathrm{E}$ & $202 \mathrm{M}$ & $203 \mathrm{M}$ & $209 \mathrm{M}$ & $301 \mathrm{~L}$ & $303 \mathrm{~L}$ & $306 \mathrm{~L}$ \\
\hline Acid & 0.85 & 16 & 16 & 5 & 22 & 22 & 16 & 11 & 11 & 22 \\
\hline Bitter & 0.66 & 66 & 77 & 66 & 50 & 61 & 77 & 61 & 72 & 61 \\
\hline Astringent & 0.69 & 44 & 38 & 38 & 33 & 33 & 22 & 44 & 44 & 38 \\
\hline Characteristic residual flavor of coffee & 0.26 & 22 & 16 & 33 & 27 & 27 & 44 & 27 & 22 & 44 \\
\hline Smoky/tobacco & 0.86 & 16 & 22 & 16 & 16 & 11 & 5 & 16 & 11 & 16 \\
\hline Strong & 0.09 & 38 & 33 & 38 & 27 & 22 & 11 & 44 & 22 & 22 \\
\hline Slightly sweet & 0.14 & 16 & 16 & 16 & 0 & 0 & 22 & 16 & 22 & 16 \\
\hline Slightly acid & 0.01 & $27 \mathrm{ab}$ & $16 \mathrm{ab}$ & $38 \mathrm{ab}$ & 11ab & $5 b$ & $27 \mathrm{ab}$ & $22 \mathrm{ab}$ & $44 a$ & $33 \mathrm{ab}$ \\
\hline Slightly bitter & 0.67 & 16 & 16 & 22 & 16 & 22 & 0 & 11 & 16 & 16 \\
\hline Burnt & 0.13 & 33 & 38 & 33 & 27 & 33 & 5 & 50 & 27 & 16 \\
\hline Herb-like/tea & 0.21 & 33 & 16 & 27 & 11 & 5 & 16 & 16 & 5 & 16 \\
\hline Full-bodied & 0.63 & 22 & 33 & 33 & 33 & 16 & 38 & 27 & 27 & 38 \\
\hline Noncharacteristic residual flavor & 0.16 & 11 & 11 & 0 & 5 & 11 & 0 & 27 & 16 & 16 \\
\hline Chemical/resinous/medicinal & 0.10 & 5 & 16 & 5 & 0 & 0 & 5 & 22 & 16 & 0 \\
\hline Spice/black pepper/nutmeg & 0.08 & 0 & 0 & 0 & 0 & 0 & 11 & 11 & 5 & 0 \\
\hline
\end{tabular}

${ }^{(1)}$ Frequency of citation by the sensory panel (ten assessors), with two evaluations per sample. ${ }^{(2)}$ Numbers refer to the genotypes of cultivars. Means unidentified with letters do not differ significantly by the Marascuilo test, at $5 \%$ probability, from others in the same row. Means followed by different lowercase letters, in the same row, show significant difference between genotypes, by the Marascuilo test, at $5 \%$ probability.

Table 3. Contents of caffeine, total chlorogenic acids, and total titratable acidity (TTA) of conilon coffee (Coffea canephora) brews of the three genotypes of each cultivar.

\begin{tabular}{lcc}
\hline Parameter & Cultivar \\
\cline { 2 - 3 } & $\begin{array}{c}\text { Diamante ES8112 } \\
\text { (early maturing) }\end{array}$ & $\begin{array}{c}\text { ES8122 } \\
\text { (medium maturing) }\end{array}$ \\
\hline Caffeine $\left(\mu \mathrm{g} \mathrm{mL}^{-1}\right)$ & $1,300-1,660$ & $1,268-1,450$ \\
Total chlorogenic acids $\left(\mu \mathrm{g} \mathrm{mL} \mathrm{mL}^{-1}\right)$ & $689-978$ & $621-1,042$ \\
TTA $\left(\mathrm{mL}\right.$ of $\mathrm{NaOH} 0.1 \mathrm{~mol} \mathrm{~L}^{-1}$ for $20 \mathrm{~mL}$ of coffee brew) & $1.05-1.45$ & $1.25-1.50$ \\
\hline
\end{tabular}


The lowest acidity level of $C$. canephora compared with $C$. arabica has been highlighted in the literature. Coffee acidity is associated with carbohydrate degradation by the development of acids during the roasting process (Ginz et al., 2000; Schenker \& Rothgeb, 2017). It is also related to the type of grinding process: fine ground coffees show higher-beverage acidity values than medium- ground ones (Schmidt et al., 2008). Coffee brews from the genotypes of 'Diamante ES8112', 'ES8122', and 'Centenária ES8132' had lower-total titratable acidity values (Table 3) than those reported by Scholz et al. (2013) for Brazilian C. arabica beverages (2.73 to

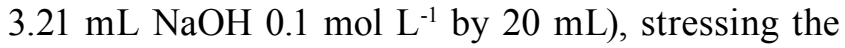
low-acidity characteristic of C. canephora brews.

Similarly to the descriptive profile, in which differences were only observed for the specific attribute of acidity (Table 1), slightly acid was the only term that stood out for a difference in citation among the beverages (Table 2). Other terms, such as burnt, smoky/tobacco, and herb-like/tea, were also mentioned by the assessors for all coffee brews, with a wide frequency of citation (from 5 to $50 \%$ ). Terms such as slightly sweet, chemical/resinous/medicinal, noncharacteristic residual flavor, spice/black pepper/ nutmeg have a frequency of citation from 0 to $27 \%$, but not for all samples.

Sensory methods based on frequency have been described as of simple and fast conduction (Minim \& Silva, 2016), but there is no report in the literature for their use to describe C. canephora brews. However, these tests are recommended for the evaluation of products with a complex aroma (Campo et al., 2010), and have already been used to evaluate wine (Campo et al., 2008). Therefore, the terms could be used to characterize $C$. canephora brews (Table 2).

\section{Conclusions}

1. The descriptive sensory profile of conilon coffee (Coffea canephora) brews, produced from clonal cultivars developed for the state of Espírito Santo, Brazil, highlights a high intensity of powder fragrance, and coffee brew quality for characteristic aroma, body, characteristic flavor, and aftertaste, and a lower intensity of bitterness, acidity, astringency, and defects.
2. The terms bitterness, strong, full-bodied, astringency, and residual flavor of coffee are the most relevant ones to characterize the coffee brews of the genotypes of $C$. canephora cultivars.

3. Acidity is the characteristic with the greatest impact on the overall quality of $C$. canephora brews.

4. Coffee brews from genotypes of 'Diamante ES8112', 'ES8122', and 'Centenária ES8132' show a good quality potential, and are classified as traditional beverages close to the superior category.

\section{Acknowledgments}

To Instituto Agronômico do Paraná (Iapar), for assistance in the roasting process; and to Conselho Nacional de Desenvolvimento Científico e Tecnológico (CNPq), for scholarships granted and financial support (Process No. 445757/2014-0).

\section{References}

ABIC. Associação Brasileira da Indústria de Café. Norma de qualidade recomendável e boas práticas de fabricação de cafés torrados em grão e cafés torrados e moídos. 2017. Revisão 29. Available at: <http://abic.com.br/src/uploads/2017/07/2.8.1Norma-de-qualidade-PQC.pdf >. Accessed on: Oct. 162017.

ACOMPANHAMENTO DA SAFRA BRASILEIRA [DE] CAFÉ: safra 2017: terceiro levantamento, v.4, n.3, set. 2017. Available at: $<$ http://www.sapc.embrapa.br/arquivos/consorcio/levantamento/ conab_safra2017_n3_vf.pdf $>$. Accessed on: Oct. 162017.

AGUIAR, A.T.E.; MALUF, M.P.; GALLO, P.B.; MORI, E.E.M.; FAZUOLI, L.C.; GUERREIRO-FILHO, O. Análise sensorial da bebida das cultivares Ouro Verde, Tupi e Obatã. In: SIMPÓSIO DE PESQUISA DOS CAFÉS DO BRASIL, 2., 2001, Vitória. Anais. Brasília: Embrapa Café, 2001. p.1242-1247. Available at: <http://www.sapc.embrapa.br/arquivos/consorcio/spcb_anais/ simposio2/genet01.pdf>. Accessed on: Oct. 162017.

ARES, G.; ETCHEMENDY, E.; ANTÚNEZ, L.; VIDAL, L.; GIMÉNEZ, A.; JAEGER, S.R. Visual attention by consumers to check-all-that-apply questions: Insights to support methodological development. Food Quality and Preference, v.32, p.210-220, 2014. DOI: 10.1016/j.foodqual.2013.10.006.

BRASIL. Ministério da Agricultura, Pecuária e Abastecimento. Instrução Normativa $n^{\circ} 16$, de 24 de maio de 2010. [Estabelece o Regulamento Técnico para o Café Torrado em Grão e Café Torrado e Moído, definindo o seu padrão oficial de classificação, com os requisitos de identidade e qualidade, a amostragem, o modo de apresentação e a marcação ou rotulagem na forma dos Anexos à presente Instrução Normativa]. Diário Oficial da União, 25 maio 2010. Seção 1, p.11-12.

BRASIL. Ministério da Agricultura, Pecuária e Abastecimento. Instrução Normativa $n^{\circ}$, de 22 de fevereiro de 2013. [Revoga a Instrução Normativa $n^{\circ} 16$, de 24 de maio de 2010, publicada 
no Diário Oficial da União do dia 25 de maio de 2010, seção 1]. Diário Oficial da União, 25 fevereiro 2013. Seção 1, p.7.

CAMPO, E.; BALLESTER, J.; LANGLOIS, J.; DACREMONT, C.; VALENTIN, D. Comparison of conventional descriptive analysis and a citation frequency-based descriptive method for odor profiling: An application to Burgundy Pinot noir wines. Food Quality and Preference, v.21, p.44-55, 2010. DOI: 10.1016/j. foodqual.2009.08.001.

CAMPO, E.; DO, B.V.; FERREIRA, V; VALENTIN, D. Aroma properties of young Spanish monovarietal white wines: a study using sorting task, list of terms and frequency of citation. Australian Journal of Grape and Wine Research, v.14, p.104115, 2008. DOI: 10.1111/j.1755-0238.2008.00010.x.

'CENTENÁRIA ES8132': nova variedade clonal de café conilon de maturação tardia para o Espírito Santo. 2.ed. rev. Vitória: Incaper, 2015. (Incaper. Documento, 221).

CORSO, M.P.; VIGNOLI, J.A.; BENASSI, M. de T. Development of an instant coffee enriched with chlorogenic acids. Journal of Food Science and Technology, v.53, p.1380-1388, 2016. DOI: 10.1007/s13197-015-2163-y.

'DIAMANTE ES8112': nova variedade clonal de café conilon de maturação precoce para o Espírito Santo. 2.ed. rev. Vitória: Incaper, 2015. (Incaper. Documento, 219).

'ES8122' JEQUITIBÁ: nova variedade clonal de café conilon de maturação intermediária para o Espírito Santo. 2.ed. rev. Vitória: Incaper, 2015. (Incaper. Documento, 220).

ESPÍRITO SANTO. Decreto n ${ }^{\circ}$ 1674-R, de 24 de maio de 2006. Define Normas Técnicas para fixação da qualidade de café torrado e moído, para fins de procedimento licitatório, no âmbito do Poder Executivo do Estado do Espírito Santo. Diário Oficial [do] Estado do Espírito Santo, 25 maio 2006. p.3-4.

FERRÃO, M.A.G.; FONSECA, A.F.A. da; FERRÃO, R.G.; BARBOSA, W.M.; SOUZA, E.M.R. Genetic divergence in Conilon coffee revealed by RAPD markers. Crop Breeding and Applied Biotechnology, v.9, p.67-74, 2009. DOI: 10.12702/19847033.v09n01a10.

FERRÃO, R.G.; FONSECA, A.F.A. da; FERRÃO, M.A.G.; DE MUNER, L.H. (Ed.). Café conilon. 2.ed. atual. e ampl. Vitória: Incaper, 2017. 784p.

GINZ, M.; BALZER, H.H.; BRADBURY, A.G.W.; MAIER, H.G. Formation of aliphatic acids by carbohydrate degradation during roasting of coffee. European Food Research and Technology, v.211, p. 404-410, 2000. DOI: 10.1007/s002170000215.

GLOESS, A.N.; SCHÖNBÄCHLER, B.; KLOPPROGGE, B.; D'AMBROSIO, L. CHATELAIN, K.; BONGARTZ, A.; STRITTMATTER, A.; RAST, M.; YERETZIAN, C. Comparison of nine common coffee extraction methods: instrumental and sensory analysis. European Food Research and Technology, v.236, p.606-627, 2013. DOI: 10.1007/s00217-013-1917-x.

LEROY, T.; RIBEYRE, F.; BERTRAND, B.; CHARMETANT, P.; DUFOUR, M.; MONTAGNON, C.; MARRACINI, P.; POT, D. Genetics of coffee quality. Brazilian Journal of Plant Physiology, v.18, p.229-242, 2006. DOI: 10.1590/S167704202006000100016 .
MENDES, L.C.; MENEZES, H.C. de; SILVA, M.A.A.P. da. Optimization of the roasting of robusta coffee (C. canephora conillon) using acceptability tests and RSM. Food Quality and Preference, v.12, p.153-162, 2001. DOI: 10.1016/S09503293(00)00042-2.

MINAS GERAIS. Decreto n 44.661, de 26 de novembro de 2007. Estabelece normas relativas à aquisição de café torrado em grão e torrado e moído pelos órgãos e entidades do Poder Executivo. Diário Oficial [de] Minas Gerais, 27 nov. 2007. p.2.

MINIM, V.P.R.; SILVA, R. de C. dos S.N. da. Métodos descritivos com consumidores. In: MINIM, V.P.R.; SILVA, R. de C. dos S.N. da. (Ed.). Análise Sensorial Descritiva. Viçosa: Ed. da UFV, 2016. p.223-260.

MORI, E.E.M.; BRAGAGNOLO, N.; MORGANO, M.A.; ANJOS, V.D.A.; YOTSUYANAGI, K.; FARIA, E.V.; IYOMASA, J.M. Brazil coffee growing regions and quality of natural, pulped natural and washed coffees. Food and Food Ingredients Journal of Japan, v.208, p.416-423, 2003.

MOURA, S.C.S.R. de; GERMER, S.P.M.; ANJOS, V.D. de A.; MORI, E.E.M.; MATTOSO, L.H.C.; FIRMINO, A.; NASCIMENTO, C.J.F. Avaliações físicas, químicas e sensoriais de blends de café arábica com Canephora (robusta). Brazilian Journal of Food Technology, v.10, p.271-277, 2007.

PARANÁ. Decreto n 2.916 , de 25 de junho de 2008. Dispõe sobre as características para a aquisição de café torrado em grão ou café torrado e moído para consumo no âmbito da Administração Pública Estadual Direta e Indireta. Diário Oficial [do] Paraná, 18 jul. 2008 . p.4.

PERRONE, D.; FARAH, A; DONANGELO, C.M. Influence of coffee roasting on the incorporation of phenolic compounds into melanoidins and their relationship with antioxidant activity of the brew. Journal of Agricultural and Food Chemistry, v.60, p. 4265-4275, 2012. DOI: 10.1021/jf205388x.

RODRIGUES, C.I.; MARTA, L.; MAIA, R.; MIRANDA, M.; RIBEIRINHO, M.; MÁGUAS, C. Application of solidphase extraction to brewed coffee caffeine and organic acid determination by UV/HPLC. Journal of Food Composition and Analysis, v.20, p.440-448, 2007. DOI: 10.1016/j.jfca.2006.08.005.

SÃO PAULO (Estado). Secretaria de Agricultura e Abastecimento. Resolução SAA n ${ }^{\circ} 28$, de 1 de junho de 2007. Define Norma Técnica para fixação de identidade e qualidade de café torrado em grão e café torrado moído. Diário Oficial [do] Estado de São Paulo, 5 jun. 2007a. Seção 1, p.27.

SÃO PAULO (Estado). Secretaria de Agricultura e Abastecimento. Resolução SAA no 31, de 22 de junho de 2007. Define Norma de Padrões Mínimos de Qualidade para Café Torrado em Grão e Torrado e Moído - Classificação Especial: Café Gourmet, como base para Certificação de Produtos pelo Sistema de Qualidade de Produtos Agrícolas, Pecuários e Agroindustriais do Estado de São Paulo, instituído pela Lei 10.481, 29/12/1999. Diário Oficial [do] Estado de São Paulo, 23 jun. 2007b.

SÃO PAULO (Estado). Secretaria de Agricultura e Abastecimento. Resolução SAA no 30, de 22 de junho de 2007. Define Norma de Padrões Mínimos de Qualidade para Café Torrado em Grão e Torrado e Moído - Característica Especial: Café Superior, 
como base para Certificação de Produtos pelo Sistema de Qualidade de Produtos Agrícolas, Pecuários e Agroindustriais do Estado de São Paulo, instituído pela Lei 10.481, 29/12/1999. Diário Oficial [do] Estado de São Paulo, 23 jun. 2007c. Seção 1, p.23-24. Available at: <http://abic.com.br/src/uploads/2017/07/ CONS_leg_resolucaoSAA30.pdf>. Accessed on: Oct. 162017.

SÃO PAULO (Estado). Secretaria de Agricultura e Abastecimento. Resolução SAA n ${ }^{\circ} 19$, de 5 de abril de 2010. Define Norma de Padrões Mínimos de Qualidade para Café Torrado em Grão e Torrado e Moído - Característica: CAFÉ TRADICIONAL. Diário Oficial [do] Estado de São Paulo, 9 abr. 2010. Seção 1, p.26-27. Available at: <http://abic.com.br/src/uploads/2017/07/ CONS_leg_resolucaosaa19.pdf/>. Accessed on: Oct. 162017.

SCAA. Specialty Coffee Association. Flavor wheel. Available at: $\quad<$ http://scaa.org/index.php?page=resources \&d=scaa-flavorwheel>. Accessed on: Dec. 122015.

SCHENKER, S.; ROTHGEB, T. The roast - creating the bean's signature. In: FOLMER, B. The craft and science of coffee. London: Academic Press, 2017. p.245-271. DOI: 10.1016/B978-012-803520-7.00011-6.

SCHMIDT, C.A.P.; MIGLIORANZA, E.; GARCIA, A. de O. FERREIRA, E.B. Caracterização dos cafés produzidos em solos basálticos e arenosos do Paraná. Revista Brasileira de Tecnologia Agroindustrial, v.6, p.688-701, 2012. DOI: 10.3895/ S1981-36862012000100008.

SCHMIDT, C.A.P.; MIGLIORANZA, E.; PRUDENCIO, S.H. Interação da torra e moagem do café na preferência do consumidor do oeste paranaense. Ciência Rural, v.38, p.1111-1117, 2008. DOI: 10.1590/S0103-84782008000400032.

SCHOLZ, M.B. dos S.; SILVA, J.V.N. da; FIGUEIREDO, V.R.G. de; KITZBERGER, C.S.G. Atributos sensoriais e características físico-químicas de bebida de cultivares de café do IAPAR. Coffee Science, v.8, p.6-16, 2013.

USDA. United States Department of Agriculture. Table 03C Robusta coffee production. Available at: $<$ http: //apps.fas.usda. gov/psdonline/psdReport.aspx?hidReportRetrievalName $=$ Table $+03 \mathrm{C}+$ Robusta + Coffee + Production\&hidReportRetrievalID $=$ 1679\&hidReportRetrievalTemplateID $=8>$. Accessed on: Oct. 16 2017.

WILLIAMS, A.A.; FERIA-MORALES, A.; KARI, P. Sensory and analytical examination of ground and cup coffee with particular reference to bean maturity. In: INTERNATIONAL SCIENTIFIC COLLOQUIUM ON COFFEE, 13., 1989, Paipa. [Proceedings]. Paipa: ASIC, 1989. p.83-106.

Received on December 16, 2016 and accepted on November 29, 2017

Pesq. agropec. bras., Brasília, v.53, n.9, p.1061-1069, Sept. 2018 DOI: 10.1590/S0100-204X2018000900010 